\title{
Long-range transport of black carbon to the Pacific Ocean and its dependence on aging timescale
}

\author{
J. Zhang ${ }^{1,2,3}$, J. Liu ${ }^{1}$, S. Tao ${ }^{1}$, and G. A. Ban-Weiss ${ }^{3}$ \\ ${ }^{1}$ Laboratory for Earth Surface Processes, College of Urban and Environmental Sciences, Peking University, Beijing, China \\ ${ }^{2}$ School of Physics, Peking University, Beijing, China \\ ${ }^{3}$ Department of Civil and Environmental Engineering, University of Southern California, Los Angeles, CA, USA
}

Correspondence to: J. Liu (jfliu@pku.edu.cn)

Received: 22 May 2015 - Published in Atmos. Chem. Phys. Discuss.: 22 June 2015

Revised: 28 September 2015 - Accepted: 29 September 2015 - Published: 20 October 2015

\begin{abstract}
Improving the ability of global models to predict concentrations of black carbon (BC) over the Pacific Ocean is essential to evaluate the impact of $\mathrm{BC}$ on marine climate. In this study, we tag BC tracers from 13 source regions around the globe in a global chemical transport model, Model for Ozone and Related Chemical Tracers, version 4 (MOZART4). Numerous sensitivity simulations are carried out varying the aging timescale of $\mathrm{BC}$ emitted from each source region. The aging timescale for each source region is optimized by minimizing errors in vertical profiles of $\mathrm{BC}$ mass mixing ratios between simulations and HIAPER Pole-to-Pole Observations (HIPPO). For most HIPPO deployments, in the Northern Hemisphere, optimized aging timescales are less than half a day for $\mathrm{BC}$ emitted from tropical and midlatitude source regions and about 1 week for BC emitted from highlatitude regions in all seasons except summer. We find that East Asian emissions contribute most to the BC loading over the North Pacific, while South American, African and Australian emissions dominate BC loadings over the South Pacific. Dominant source regions contributing to $\mathrm{BC}$ loadings in other parts of the globe are also assessed. The lifetime of $\mathrm{BC}$ originating from East Asia (i.e., the world's largest BC emitter) is found to be only 2.2 days, much shorter than the global average lifetime of 4.9 days, making the contribution from East Asia to the global BC burden only $36 \%$ of that from the second largest emitter, Africa. Thus, evaluating only relative emission rates without accounting for differences in aging timescales and deposition rates is not predictive of the contribution of a given source region to climate impacts. Our simulations indicate that the lifetime of BC increases nearly linearly with aging timescale for all source regions. When
\end{abstract}

the aging rate is fast, the lifetime of $\mathrm{BC}$ is largely determined by factors that control local deposition rates (e.g., precipitation). The sensitivity of lifetime to aging timescale depends strongly on the initial hygroscopicity of freshly emitted BC. Our findings suggest that the aging timescale of $\mathrm{BC}$ varies significantly by region and season and can strongly influence the contribution of source regions to $\mathrm{BC}$ burdens around the globe. Therefore, improving parameterizations of the aging process for $\mathrm{BC}$ is important for enhancing the predictive skill of global models. Future observations that investigate the evolution of the hygroscopicity of $\mathrm{BC}$ as it ages from different source regions to the remote atmosphere are urgently needed.

\section{Introduction}

Black carbon (BC) is an efficient absorber of solar radiation and therefore heats the atmosphere and the Earth surface (Ramanathan and Carmichael, 2008). Estimates of BC's direct radiative forcing vary widely, ranging from $0.19 \mathrm{~W} \mathrm{~m}^{-2}$ by Wang et al. (2014) to $0.88 \mathrm{~W} \mathrm{~m}^{-2}$ by Bond et al. (2013). The Intergovernmental Panel on Climate Change Fifth Assessment Report (IPCC, 2013) assesses the direct radiative forcing of $\mathrm{BC}$ to be $0.40 \mathrm{~W} \mathrm{~m}^{-2}$, with a large uncertainty range of 0.05 to $0.80 \mathrm{~W} \mathrm{~m}^{-2}$. Besides its direct radiative effects, BC also affects Earth's energy budget indirectly by influencing cloud formation (Koch and Del Genio, 2010) and snow albedo (Hansen and Nazarenko, 2004; Flanner et al., 2007; He et al., 2014), although these processes are less well understood and subject to greater uncertainties. In addition, 
epidemiological studies have shown that BC is associated with increased hospital admissions and premature mortalities (Bell et al., 2009; Janssen et al., 2011).

Relative to greenhouse gases, BC has a shorter lifetime, and its concentration changes considerably by location and season (Liu et al., 2011). Horizontal and vertical distributions of $\mathrm{BC}$ are not well constrained by observations, contributing to the uncertainties in estimates of BC's radiative forcing (Bond et al., 2013). BC has higher radiative forcing efficiency (i.e., radiative forcing per unit mass of $\mathrm{BC}$ ) when its underlying surface is highly reflective (e.g., cloud, snow and ice). The radiative forcing of $\mathrm{BC}$ also depends on its attitude and is enhanced if $\mathrm{BC}$ is located above clouds rather than below clouds (Satheesh, 2002; Zarzycki and Bond, 2010). The direct radiative forcing efficiency of $\mathrm{BC}$ may increase by a factor of 10 as altitude increases from the surface to the lower stratosphere (Samset and Myhre, 2011), whereas forcing associated with the semi-direct effect (i.e., changes in cloudiness due to local heating from $\mathrm{BC}$ ) becomes more negative as altitude increases (Samset and Myhre, 2015). On the other hand, the climate response of BC depends on altitude in different ways than forcing. Since BC warms its surroundings, near-surface $\mathrm{BC}$ can warm the surface more than $\mathrm{BC}$ at high altitudes, even though the high-altitude $\mathrm{BC}$ has higher top-of-atmosphere direct radiative forcing efficiency. BC at high altitudes could even cause surface cooling (Ban-Weiss et al., 2012; Samset et al., 2013). Near-surface BC has also been found to increase precipitation, whereas $\mathrm{BC}$ at higher altitudes can suppress precipitation (Ming et al., 2010; BanWeiss et al., 2012; Samset and Myhre, 2015).

$\mathrm{BC}$ over oceans could potentially play a significant role in changing the marine climate through influences on the topof-atmosphere and surface energy balance, as well as temperature and cloud profiles. For instance, BC over the Arabian Sea has been shown to dim the surface, decrease sea surface temperature, reduce monsoon circulation and vertical wind shear, and consequently increase the intensity of cyclones (Evan et al., 2011). The Pacific Ocean is the largest ocean in the world, extending from the Arctic to the Antarctic. Its marine climate has been shown to influence the weather and environment in neighboring continents, for example the South Asian and East Asian summer monsoon (Bollasina et al., 2011; Lau and Nath, 2012; Liu Y. K. et al., 2013; Bollasina et al., 2014). Recently, the HIAPER Pole-to-Pole Observation (HIPPO) campaign has enabled further research on trans-Pacific transport of BC. HIPPO's five deployments provide new constraints for modeling the vertical structures of $\mathrm{BC}$ at a wide range of latitudes over the Pacific, spanning all seasons (Wofsy et al., 2011; Kipling et al., 2013). Past model intercomparison studies have shown that a collection of global models predict $\mathrm{BC}$ concentrations that are a factor of 3 and 10 higher than HIPPO observations in the lower and upper troposphere, respectively (Schwarz et al., 2013); the vertical profiles simulated by the 15 global models markedly differ (Samset et al., 2014).
The aforementioned inter-model differences and disagreement between models and HIPPO observations can be attributed to the uncertainties in emissions and meteorology, along with different treatments of convective transport and deposition (Koch et al., 2009; Vignati et al., 2010). Wetscavenging processes are a major source of uncertainty in predicting $\mathrm{BC}$ concentrations over remote regions (Textor et al., 2007; Schwarz et al., 2010). As emitted, BC is mostly hydrophobic (Laborde et al., 2013) but can become coated with water-soluble components through atmospheric aging processes. The coatings change $\mathrm{BC}$ from being hydrophobic to hydrophilic, allowing the $\mathrm{BC}$-containing particles to become cloud condensation nuclei and be scavenged by precipitation (Riemer et al., 2010; Oshima and Koike, 2013). The exponential timescale for this aging process to occur, the socalled "aging timescale", which is also the reciprocal of the aging rate, therefore greatly influences the timing of cloud formation and wet deposition and is thus of great research interest (Liu et al., 2011). The thickness of BC coatings has been observed to increase with aging at the remote marine Pico Mountain Observatory, which shows that the fraction of coated particles for plumes with an age of $\sim 15.7$ days is $87 \%$, higher than that of $\sim 9.5$ days, $85 \%$ (China et al., 2015). Quantitatively relating the age of BC-containing particles to hygroscopicity using observations is very challenging (McMeeking et al., 2011). Laboratory measurements show that $\mathrm{BC}$ particles are considerably hygroscopic after being coated with condensed $\mathrm{H}_{2} \mathrm{SO}_{4}$ (Zhang et al., 2008) or when a sulfur-containing compound is added to the diesel fuel itself, presumably also leading to a sulfuric coating (Lammel and Novakov, 1995). The oxidation of organic coatings on $\mathrm{BC}$ by ozone and nitrogen oxide is also highlighted as an important pathway to aging in chamber studies (Kotzick et al., 1997; Kotzick and Niessner, 1999). Another study reporting observations in the United Kingdom finds that nitrate is the primary component of the coating on $\mathrm{BC}$ that leads to substantial increases in hygroscopicity (Liu D. et al., 2013). In principle, the conversion of hydrophobic to hydrophilic $\mathrm{BC}$ is very complicated, involving coagulation with sulfate and nitrate, condensation of nitric and sulfuric acid, and oxidation of organic coatings (Riemer et al., 2004; Matsui and Koike, 2012).

The aforementioned uncertainties in process and timescale for atmospheric aging, which converts BC from being hydrophobic to hydrophilic, leads to significant uncertainties in the transport of $\mathrm{BC}$ from source regions to remote areas. For example, previous studies that look at source regions of Arctic BC disagree on the relative importance of contributions from North American, Asian, and European emissions (Koch and Hansen, 2005; Shindell et al., 2008; Bourgeois and Bey, 2011; Wang et al., 2014). BC over the North Pacific Ocean is significantly influenced by the long-range transport of BC from Asia (Kaneyasu and Murayama, 2000). Eastern and central Asia are regarded as the most significant contributors to BC burden above the oceans in the Northern Hemi- 
sphere (Ma et al., 2013a). However, the source of BC over the Pacific Ocean at different latitudes and altitudes remains unclear.

The major objectives of this study are to understand the sensitivity of the BC aging timescale on its loading and source attribution using a global chemical transport model. We quantify the relative contributions of 13 source regions to $\mathrm{BC}$ loadings around the globe, with a focus on BC over the Pacific Ocean. In Sect. 2, we improve the model by implementing physically based dry- and wet-deposition schemes. We also tag BC emitted from different source regions and conduct sensitivity tests to investigate how different aging timescales affect spatial (i.e., horizontal and vertical) distributions and source-receptor relationships for BC. In Sect. 3, we optimize the aging timescale of $\mathrm{BC}$ for each source region to attain the best match with HIPPO observations. Section 4 identifies the most significant contributors to $\mathrm{BC}$ over the Pacific Ocean, and quantifies the source-receptor relationship. We also discuss the relationship between lifetime and aging timescales of BC in Sect. 5.

\section{Method}

\subsection{Model description and configuration}

In this research, we use the Model for Ozone and Related Chemical Tracers, version 4 (MOZART-4; Emmons et al., 2010), a global chemical transport model developed at the National Center for Atmospheric Research (NCAR). Built using the framework of the Model of Atmospheric Chemistry and Transport (MATCH; Rasch et al., 1997) with a series of updates, MOZART-4 resolves horizontal and vertical transport, chemistry, and dry and wet deposition of 85 gasphase and 12 bulk aerosol species. Vertical transport considers both diffusion in the boundary layer using the Holtslag and Boville (1993) scheme, convective mass flux using the Hack (1994) scheme for shallow and middle convection, and the Zhang and McFarlane (1995) scheme for deep convection. Horizontal transport is characterized by a semiLagrangian advection scheme (Lin and Rood, 1996) with a pressure fixer (Horowitz et al., 2003). In the standard model, $\mathrm{BC}$ is represented by two classes of tracers: hydrophobic and hydrophilic. Hydrophobic BC accounts for $80 \%$ of BC emissions and converts to hydrophilic $\mathrm{BC}$ with an exponential aging timescale of about 1.6 days. Only hydrophilic BC can be wet scavenged. Its first-order wet-scavenging rate is set to $20 \%$ of that for nitric acid, and it is proportional to precipitation rate. Precipitation is produced by stratiform clouds (i.e., large-scale precipitation) and convective clouds (i.e., convective precipitation). Dry-deposition velocity for both $\mathrm{BC}$ tracers is set to $0.1 \mathrm{~cm} \mathrm{~s}^{-1}$ (Emmons et al., 2010).

The model is run at a horizontal resolution of approximately $1.9^{\circ} \times 1.9^{\circ}$ (latitude $\times$ longitude) with 28 vertical levels from the surface to approximately $2 \mathrm{hPa}$, and it is driven by NCEP reanalysis meteorology. Anthropogenic emissions are based on the MACCity emission inventory (http://www.pole-ether.fr/eccad), which is extended from the database used for the IPCC Coupled Model Intercomparison Project (Lamarque et al., 2010). Biomass burning emissions are acquired from the Global Fire Emissions Database (GFED) version 3 (van der Werf et al., 2010). Model simulations are for 1 January 2008 to 31 December 2011, and the first year of the simulation is discarded as model spin-up.

\subsection{Dry- and wet-deposition schemes}

To improve model performance, we employ the drydeposition parameterization (Eq. 1) from Gallagher et al. (2002)

$$
\begin{aligned}
& v_{\mathrm{d}}=\frac{1}{r_{\mathrm{a}}+r_{\mathrm{s}}}, r_{\mathrm{s}}=\left(u ^ { * } \left(0.001222 \log \left(z_{0}\right)\right.\right. \\
& \left.\left.+0.0009\left(\frac{z_{\mathrm{i}}}{L}\right)^{\frac{2}{3}}+0.003906\right)\right)^{-1}
\end{aligned}
$$

where $v_{\mathrm{d}}$ is the dry-deposition rate $\left(\mathrm{m} \mathrm{s}^{-1}\right), r_{\mathrm{a}}$ is aerodynamic resistance, $r_{\mathrm{s}}$ is surface resistance, $u^{*}$ is friction velocity $\left(\mathrm{m} \mathrm{s}^{-1}\right), z_{0}$ is the roughness length $(\mathrm{m}), z_{i}$ is boundary layer depth (m), and $L$ is the Monin-Obukhov length (m). As a result, dry-deposition velocity depends on surface properties (e.g., vegetation type).

For in-cloud wet scavenging of $\mathrm{BC}$, we follow the parameterization used in Liu et al. (2011). The first-order in-cloud scavenging rate coefficient $\left(\mathrm{s}^{-1}\right)$ is expressed as

$K_{\text {in }}=\frac{P_{\text {rain }} F_{\text {liq }}+P_{\text {snow }} F_{\text {ice }}+P_{\text {conv }} F_{\text {conv }}}{C}$,

where $P_{\text {rain }}, P_{\text {snow }}$, and $P_{\text {conv }}$ are the rates of stratiform rain precipitation, stratiform snow precipitation, and convective precipitation $\left(\mathrm{kg} \mathrm{m}^{-3} \mathrm{~s}^{-1}\right)$, respectively, and $C$ is the sum of cloud ice and liquid water content $\left(\mathrm{kg} \mathrm{m}^{-3}\right)$. For convective clouds, $F_{\text {conv }}$ is the fraction of in-cloud hydrophilic BC that is incorporated into cloud droplets or ice crystals. For stratiform clouds, $F_{\text {liq }}\left(F_{\text {ice }}\right)$ is the fraction of in-cloud hydrophilic $\mathrm{BC}$ that is incorporated into liquid cloud droplets (ice crystals).

As previous studies indicate, the fraction of $\mathrm{BC}$ that is incorporated into cloud droplets or ice crystals decreases as temperature decreases and ice mass fraction increases in mixed-phase clouds (Croft et al., 2010, 2012; Liu et al., 2011; Fan et al., 2012). This phenomenon is attributable to the so-called Bergeron process, by which ice crystals grow rapidly at the expense of liquid droplets, leaving BCcontaining cloud nuclei interstitial (i.e., not activated; Cozic et al., 2007). However, the Bergeron process is not important in deep convective clouds where ice forms rapidly via rimming or accretion. Thus, generally $F_{\text {ice }}<F_{\text {liq }}<F_{\text {conv }}$. In this study, we set $F_{\text {ice }}=0.1, F_{\text {liq }}=0.5$, and $F_{\text {conv }}=1.0$ based on previous studies (Liu et al., 2011; Wang et al., 2011; Hodnebrog et al., 2014). 


\subsection{HIAPER Pole-to-Pole Observations}

The HIPPO campaigns unprecedentedly provide vertical profiles from the surface to the upper troposphere for 26 species over the Pacific Ocean, spanning from approximately $90^{\circ} \mathrm{N}$ to $70^{\circ} \mathrm{S}$, in different seasons (Wofsy et al., 2011). BC is measured by a single-particle soot photometer (SP2) using laser-induced incandescence (Schwarz et al., 2010). The SP2 heats $\mathrm{BC}$-containing particles to its vaporization temperature and measures the resulting incandescence emitted by the $\mathrm{BC}$ core. Since the intensity of incandescence responds linearly to the mass of refractory BC, SP2 measures BC mass independent of particles' morphology and mixing state (Schwarz et al., 2006, 2008). We constrain and evaluate our model by comparing simulated vertical profiles of $\mathrm{BC}$ mass mixing ratios over the central Pacific Ocean to observations from five field deployments (HIPPO I on 8-30 January 2009; HIPPO II on 31 October-22 November 2009; HIPPO III on 24 March16 April 2010; HIPPO IV on 14 June-11 July 2011; HIPPO V on 9 August-9 September 2011). Note that we use only the HIPPO observations taken in the central Pacific Ocean $\left(130^{\circ} \mathrm{W}-160^{\circ} \mathrm{E}\right)$ and ignore observations near source regions.

\subsection{Tracer tagging and sensitivity simulations}

In this study, we add 13 tracers to the model to explicitly track BC emissions from non-overlapping geopolitical regions, an approach often called "tagging" (Rasch et al., 2000). Tagging is more accurate and less computationally demanding than the widely used emission sensitivity approach (Wang et al., 2014). We expand the 10 defined continental regions in Liu et al. (2009) to 13 source regions to better distinguish the differences in climate and emission source type between regions. As shown in Fig. 1, the tagged source regions are Canada (CA), North America except Canada (NA), East Asia (EA), the former Soviet Union (SU), Europe (EU), Africa (AF), South America (SA), the Indian subcontinent (IN), Australia (AU), Middle Asia (MA), Southeast Asia (SE), the Middle East (ME), and the remaining regions (RR). For each simulation, the tagged tracers undergo transport and deposition processes in the same way as untagged BC. Since all the chemical and physical processes involving BC are nearly linear in MOZART-4, the relative difference between the sum of the 13 regional $\mathrm{BC}$ tracers and the untagged $\mathrm{BC}$ is small (i.e., in most cases less than $1 \%$, with the largest biases less than $4 \%$ ). Therefore, the sum of the 13 regional $\mathrm{BC}$ tracers is approximately equal to the untagged $\mathrm{BC}$.

In the model, two parameters control the hygroscopicity of BC: initial fraction of hydrophilic BC in freshly emitted BC $(20 \%)$ and a fixed e-folding aging timescale, which characterizes the timescale for conversion of hydrophobic $\mathrm{BC}$ to hydrophilic $\mathrm{BC}$ in the atmosphere. The hygroscopicity of $\mathrm{BC}$-containing particle determines whether $\mathrm{BC}$ can be wet scavenged and thus affects the lifetime of BC. Therefore,

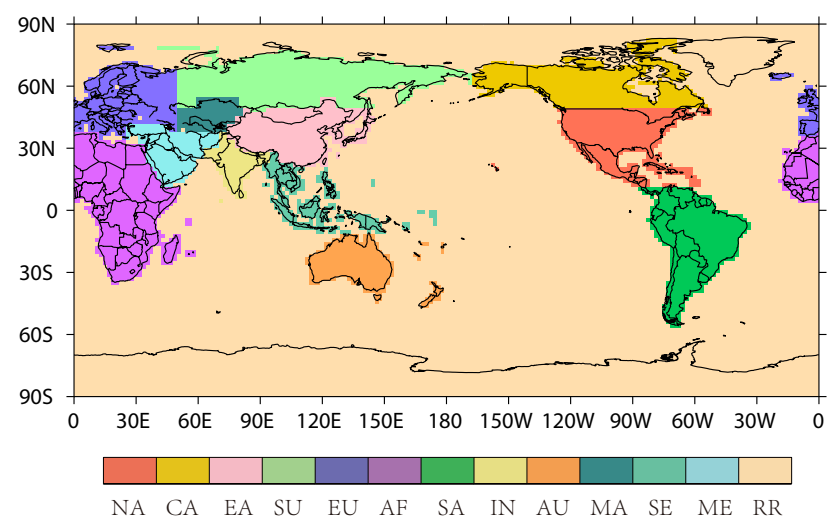

Figure 1. The 13 defined source regions: Canada (CA), North America except Canada (NA), East Asia (EA), the former Soviet Union (SU), Europe (EU), Africa (AF), South America (SA), India (IN), Australia (AU), Middle Asia (MA), Southeast Asia (SE), the Middle East (ME), and the remaining regions (RR).

constraining the aging timescale is essential for accurately simulating long-range transport and atmospheric concentrations of BC. In global models, the e-folding aging timescale is often fixed at 1.2 or 1.6 days ( 27.6 or $38.4 \mathrm{~h}$ ), even though studies find it can vary from several hours to 2 weeks in different regions (Liu et al., 2011; Shen et al., 2014). So we conduct 13 sensitivity simulations with different e-folding aging timescales (i.e., 4, 8, 12, 18, 24, 27.6, 38.4, 48, 60, 90, 120, 160 , and $200 \mathrm{~h}$ ). Note that while we define aging timescale as the time it takes for $\mathrm{BC}$ to be converted from hydrophobic to hydrophilic, some other studies use this term to describe the change from thinly to thickly coated BC (Moteki et al., 2007; Saikawa et al., 2009).

\subsection{Optimization of BC aging timescale to match HIPPO observations}

The conversion of hydrophobic BC to hydrophilic BC in global chemistry transport models is often expressed by a fixed exponential aging timescale of 1 to 2 days (e.g., 1.2 days in GEOS-chem, 1.6 days in MOZART-4; Feng, 2007; Wang et al., 2011). However, previous studies have indicated that the aging rate of $\mathrm{BC}$ varies spatially and temporally due to different atmospheric photochemical conditions and coemitted species (Liu et al., 2011; Huang et al., 2013; Shen et al., 2014). Aging rate peaks during summer daytime and in low-latitude regions because high $\mathrm{OH}$ concentrations promote the production of water-soluble condensable species. The aging rate is slower at night and during winter because $\mathrm{OH}$ concentrations are low and thus coagulation, which is slower than condensation, dominates the formation of internally mixed BC (Riemer et al., 2004; Liu et al., 2011; Bian et al., 2013). Observations show that biomass-burning-emitted $\mathrm{BC}$, compared with urban $\mathrm{BC}$, has a larger number fraction of coated particles ( $70 \%$ vs. $9 \%$ ) and thicker coatings $(65 \mathrm{~nm}$ 
vs. $20 \mathrm{~nm}$; Schwarz et al., 2008). Different source regions are distinct in their source types (e.g., anthropogenic, biomass burning) and concentrations of oxidants. Therefore, $\mathrm{BC}$ emitted from different regions should undergo aging on different timescales.

In this study, we optimize the aging timescales of BC emitted from 13 source regions to best match the HIPPO observations. For each HIPPO deployment, we compare observations vs. simulations from $70^{\circ} \mathrm{S}$ to $90^{\circ} \mathrm{N}$ and 0 to $10 \mathrm{~km}$ along the HIPPO trajectory. The absolute deviation between modeled $\mathrm{BC}\left(\mathrm{BC}_{\mathrm{m}}\right)$ and observed $\mathrm{BC}\left(\mathrm{BC}_{\mathrm{o}}\right)$ mass mixing ratios for each latitude and altitude is calculated, and the average of the mean normalized absolute error (MNAE) is then used as an indicator of the model performance in each deployment:

MNAE $=\frac{1}{N} \sum_{n \text { lat } n \text { alt }} \frac{\operatorname{Abs}\left(\mathrm{BC}_{\mathrm{m}}(j, k)-\mathrm{BC}_{\mathrm{o}}(j, k)\right)}{\operatorname{Min}\left(\mathrm{BC}_{\mathrm{m}}(j, k), \mathrm{BC}_{\mathrm{o}}(j, k)\right)}$,

where $j$ indexes latitude bins, $k$ indexes altitude bins, $n$ lat $=16$ is the total number of latitude bins (every $10^{\circ}$ from $70^{\circ} \mathrm{S}$ to $90^{\circ} \mathrm{N}$ ), and $n$ alt $=10$ is the total number of altitude bins (every $1 \mathrm{~km}$ from 0 to $10 \mathrm{~km}$ ). Abs $\left(\mathrm{BC}_{\mathrm{m}}(j, k)-\mathrm{BC}_{\mathrm{o}}(j, k)\right)$ represents the absolute value of modeled $\mathrm{BC}$ minus observed $\mathrm{BC}$ averaged over the $j$ th and $k$ th latitude and altitude bin. $N$ is the total number of latitude and altitude bins with recorded HIPPO observations. The model output daily averaged $\mathrm{BC}$ mixing ratios. For every record in HIPPO data (averaged in every $10 \mathrm{~s}$ ), we find a corresponding modeled $\mathrm{BC}$ mixing ratio at the same longitude, latitude, altitude, and on the same day. In this way, modeled and observed $\mathrm{BC}$ mixing ratios are paired and are then averaged over latitude and altitude bins. We normalize the absolute errors by the minimum of observed and modeled BC so that MNAE weights both high bias and low bias equally. Unlike the root mean square error, the MNAE does not amplify the importance of the outliers.

Aging timescale affects atmospheric concentrations of BC through its influence on hygroscopicity and wet deposition of the particle. Thus, $\mathrm{BC}_{\mathrm{m}}(j, k)$ and MNAE are functions of aging timescale. We perform 13 simulations, each with different constant aging timescales (i.e., 4, 8, 12, 18, 24, 27.6, $38.4,48,60,90,120,160$ or $200 \mathrm{~h}$ ). Every simulation tags $\mathrm{BC}$ from each of 13 regions (East Asia and Canada); as mentioned in Sect. 2.3, $\mathrm{BC}_{\mathrm{m}}(j, k)=\sum_{\mathrm{r}} \mathrm{BC}_{\mathrm{m}}(j, k, r)$, where $r$ denotes each region. We construct $\mathrm{BC}_{\mathrm{m}}(j, k)$ using all possible combinations of $\mathrm{BC}_{\mathrm{m}}(j, k, r)$ from the 13 simulations. Then we check which combination of $\mathrm{BC}_{\mathrm{m}}(j, k, r)$ best matches $\mathrm{BC}$ observations. Note that we constrain the aging rates of BC emitted from Africa, South America, and Australia to be the same since these three regions are all biomass-burningdominated sources in the Southern Hemisphere, which effectively reduces the total number of tagged tracers from 13 to 11 . Thus, we determine the best-fit $\mathrm{BC}$ aging timescale for each source region (out of $13^{11}$ combinations in total) that minimizes the MNAE.

\section{Optimized BC profiles over the Pacific Ocean}

To give a sense of the influence of aging timescale on $\mathrm{BC}$, global $\mathrm{BC}$ burdens for the minimum and maximum aging timescales considered here (i.e., 4 and $200 \mathrm{~h}$ ) are shown in Fig. 2. BC burden increases with aging timescale in both the lower (Fig. 2d, e) and mid- and upper troposphere (Fig. 2a, b). For most regions, BC burden in remote areas and in the mid- and upper troposphere is more sensitive to aging timescale than that in source regions and in the lower troposphere (Fig. 2c, f). BC over the Pacific Ocean increases by a factor of 5-100 as the aging timescale increases from 4 to $200 \mathrm{~h}$ (Fig. 2c, f).

The dominant regional contributors to the annual averaged $\mathrm{BC}$ burden for aging timescales of 4 and $200 \mathrm{~h}$ are shown in Fig. 3. Longer aging timescales increase the footprint areas dominated by the highest-emitting source regions. For example, the area over the Pacific Ocean for which East Asian emissions dominate the burden is larger when the aging timescale is $200 \mathrm{~h}$ rather than $4 \mathrm{~h}$. Over source regions, BC in the lower troposphere is dominated by local emissions for both aging timescales. However, the dominant source of BC in the mid- and upper troposphere over source regions can switch from local source emissions to long-range transport from other source regions with increasing aging timescale. For example, BC in the mid- and upper troposphere over the United States is dominated by local emissions when the aging timescale is $4 \mathrm{~h}$ but dominated by East Asian emissions when the aging timescale is $200 \mathrm{~h}$. Thus, a varying aging timescale can lead to substantial differences in BC simulation over the Pacific Ocean, supporting the need to constrain the aging timescale by observations.

Optimized aging timescales for each source region and season are shown in Table 1. Ranges of plausible values for each optimized aging timescale based on perturbation simulations are also summarized in Table S1 in the Supplement. As shown in Table 1, values differ significantly by source region and season. The aging timescale of $\mathrm{BC}$ from East Asia, North America, India, and Southeast Asia is in most cases relatively short (i.e., less than half a day). The optimized BC timescales reported here for East Asia and North America are consistent with observations in these regions, which show that $\mathrm{BC}$ is quickly mixed with hydrophilic species. For instance, observations over an urban region of Japan find that the timescale for BC to become internally mixed is $12 \mathrm{~h}$, with coatings made of primarily sulfate and soluble organic carbon (Moteki et al., 2007). In Beijing and Mexico City, urban BC is observed to become internally mixed with sulfate within a few hours (Johnson et al., 2005; Cheng et al., 2012). Over Southeast Asia, BC emissions are mainly anthropogenic in origin (with a fast aging rate), except during 

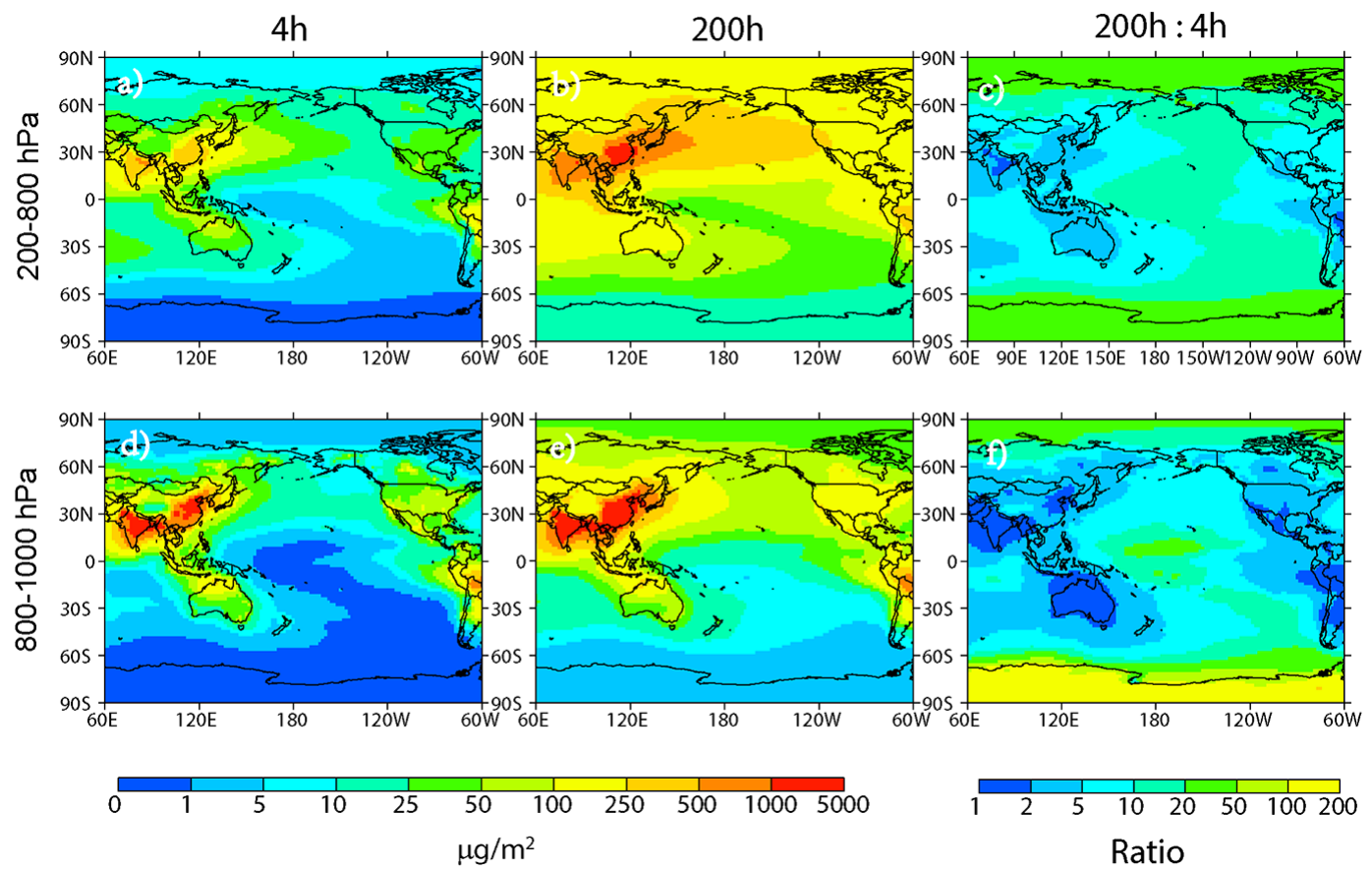

Figure 2. The annual averaged (2009-2011) column burden of BC at 200-800 hPa (a, b) and 800-1000 hPa (d, e) when aging timescale is $4 \mathrm{~h} \mathrm{(a,d)} \mathrm{and} 200 \mathrm{~h}(\mathbf{b}, \mathbf{e})$. The ratio of BC burden for simulations with aging timescale of $200 \mathrm{~h}$ and $4 \mathrm{~h}$ is shown in (c) and (f).

spring when large-scale biomass burning activities generate tremendous amounts of $\mathrm{BC}$. The optimized springtime $\mathrm{BC}$ aging timescale for Southeast Asia is around 2 days, consistent with the findings of Shen et al. (2014). On the contrary, the optimized aging rate is relatively slow in the high-latitude regions (Canada, the former Soviet Union and in particular Europe) in all seasons except summer (June-July-August, JJA), which can be explained by slower photochemistry at high latitudes under low sunlight in non-summer months. Since measurements on BC aging timescales are scarce and limited to a few places, more observations are needed to measure the hygroscopicity of BC-containing particles in different continents covering both source and downwind areas.

The seasonality of the aging timescale reported here is largely consistent with Liu et al. (2011), who develop a parameterization for $\mathrm{BC}$ aging rate as a function of $\mathrm{OH}$ radical concentration. In this study, we further improve the parameterization of Liu et al. (2011) by finding best-fit values for constants that best match HIPPO observations with reference to our $\mathrm{BC}$ aging timescales. After conducting additional sensitivity simulations, we find that a set of parameters (i.e., $\beta=2.4 \times 10^{-11}$ and $\gamma=1 \times 10^{-6}$ in Eq. (3) in Liu et al., 2011) when employed in MOZART-4 can fit the HIPPO observations as well as ground observations well (see Figs. S1 and $\mathrm{S} 2$ in the Supplement).

Figure 4 compares vertical profiles of $\mathrm{BC}$ simulated by the "improved model" and the "original model" with HIPPO observations in different latitude bands. Here, BC from the improved model is computed as the sum of tagged tracers corresponding to the optimized timescale for each region, whereas that from the original model uses the default configuration with an aging timescale of 1.6 days. The vertical profiles of BC simulated by the improved model are much closer to the observations than the original model, which overestimates $\mathrm{BC}$ mass mixing ratios in nearly every campaign. In particular, values simulated by the improved model are near those for HIPPO2, 3 and 4 in both pattern and magnitude. The MNAE is reduced significantly for each latitude band and HIPPO campaign, with reductions ranging from a factor of 2 to 25 (Fig. 4). Campaign-averaged MNAE is also reduced by a factor of 4-10 (Table 1). For comparison, we also derive the mean normalized bias (MNB) used in Samset et al. (2014). Values for the improved model are below $25 \%$ for every campaign (Table 1), lower than their reported MNB for most AeroCom models. Figure S3 shows that the improved model also agrees with the surface air observations of BC in source regions over the United States, Europe and East Asia.

In a few cases, relatively large differences between the improved model and observations remain. These differences could be attributed to any number of factors (e.g., emissions, transport, cloud and/or precipitation, aging process, wet removal efficiency). For example, models could misrepresent $\mathrm{BC}$ wet deposition due to biases in precipitation. As shown in Fig. S4, though MOZART-4 generally captures the spatial extent of precipitation during all HIPPO campaigns well, biases occasionally appear when comparing results to the NCEP reanalysis over the western Pacific. As another ex- 
Table 1. Best-fit aging timescales for 13 regional BC tracers (units: hours), the mean normalized absolute error (MNAE) for the improved model (imp) and the original model (ori), and the mean normalized bias (MNB) for the improved model compared to the vertical profiles measured by HIPPO.

\begin{tabular}{|c|c|c|c|c|c|c|c|c|c|c|c|c|c|c|c|c|c|}
\hline & & $\mathrm{CA}$ & SU & $\mathrm{EU}$ & MA & EA & $\mathrm{ME}$ & NA & SE & IN & $\mathrm{AF}$ & SA & $\mathrm{AU}$ & $\mathrm{RR}$ & $\begin{array}{r}\text { MNAE } \\
\text { (imp) }\end{array}$ & $\begin{array}{r}\text { MNAE } \\
\text { (ori) }\end{array}$ & $\begin{array}{r}\text { MNB* }^{*} \\
\text { (imp) }\end{array}$ \\
\hline HIPPO1 & January & 200 & 90 & 120 & 120 & 4 & 12 & 160 & 4 & 4 & 4 & 4 & 4 & 90 & 3.8 & 26.2 & 0.04 \\
\hline HIPPO2 & November & 200 & 160 & 160 & 90 & 4 & 4 & 4 & 4 & 4 & 90 & 90 & 90 & 200 & 2.0 & 13.1 & 0.17 \\
\hline HIPPO3 & April & 200 & 200 & 200 & 200 & 38 & 200 & 4 & 38 & 27 & 24 & 24 & 24 & 200 & 1.5 & 6.1 & -0.05 \\
\hline HIPPO4 & June & 60 & 4 & 160 & 12 & 4 & 160 & 4 & 4 & 4 & 4 & 4 & 4 & 200 & 1.1 & 10.6 & 0.11 \\
\hline HIPPO5 & August & 120 & 4 & 18 & 4 & 4 & 4 & 4 & 4 & 4 & 60 & 60 & 60 & 4 & 2.4 & 18.4 & 0.23 \\
\hline
\end{tabular}

${ }^{*} \mathrm{MNB}=\frac{1}{N} \sum_{n \text { lat } n \text { alt }} \frac{\mathrm{BC}_{\mathrm{m}}(j, k)-\mathrm{BC}_{\mathrm{o}}(j, k)}{2}$

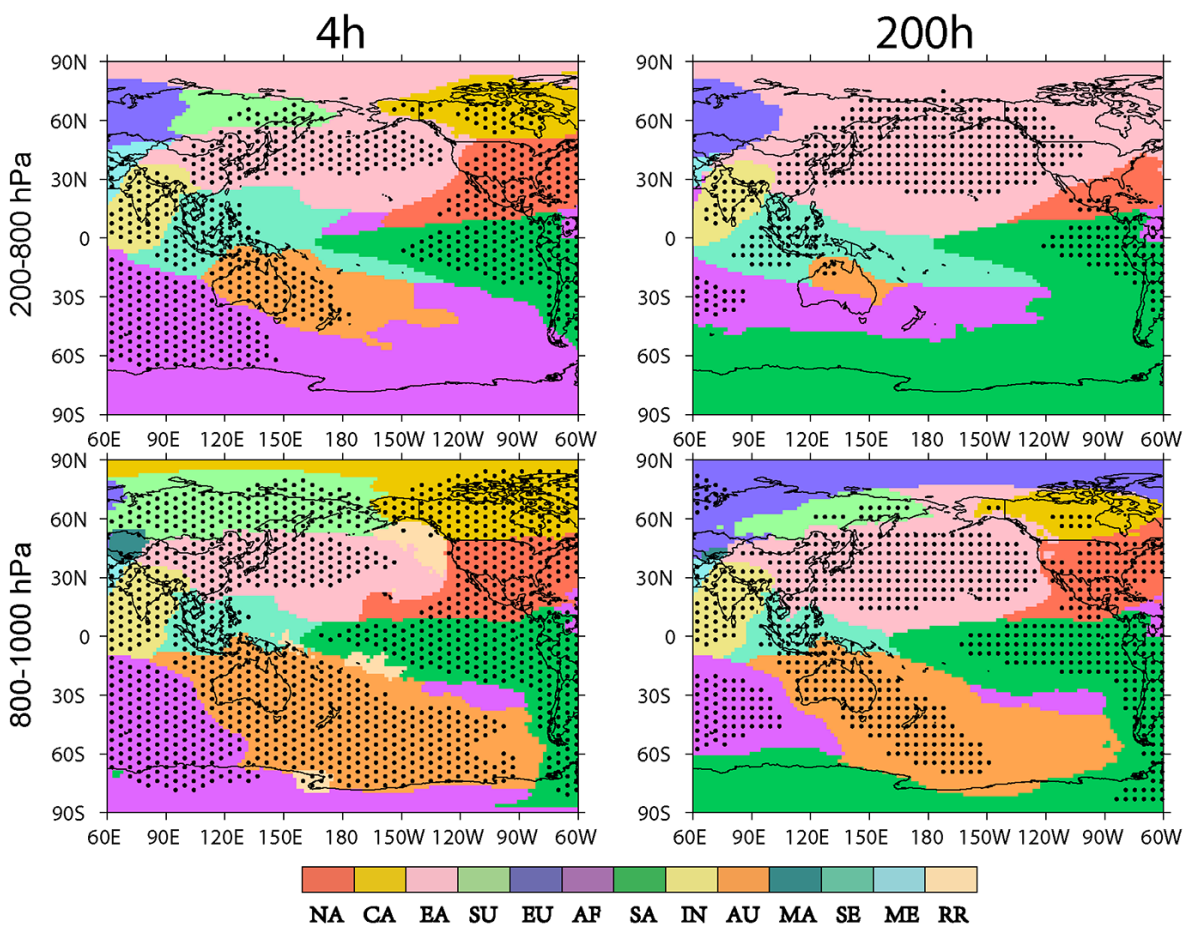

Figure 3. The dominant regional contributors to the annual averaged (2009-2011) column burden of BC at 200-800 (top) and 800-1000 hPa (bottom) when aging timescale is 4 (left) and $200 \mathrm{~h}$ (right). Dotted areas are where the dominant contributors account for more than $50 \%$ of the total BC burden.

ample, the model uses a monthly biomass burning emission inventory. This means that modeled emissions lack daily variation in biomass burning activities that could be important where biomass burning emissions dominate BC loading. Underestimates in $\mathrm{BC}$ mixing ratio may be partially due to abrupt emissions events that are not captured by the model. Lastly, since this study assumes that $\mathrm{BC}$ aging timescale in all the southern hemispheric continents is the same, we do not account for variability in $\mathrm{BC}$ aging rates from these regions although it may exist in reality.

\section{Regional contribution of source regions to $\mathrm{BC}$ loading}

Seasonally varying optimized aging timescales for each source region are used to investigate the dominant source regions contributing to the zonal mean mass mixing ratio of $\mathrm{BC}$ over the Pacific Ocean $\left(130^{\circ} \mathrm{W}-160^{\circ}\right.$ E; Fig. $\left.5 \mathrm{a}\right)$ and the column burden of $\mathrm{BC}$ around the globe (Fig. 5b). We assume that optimized aging timescales for HIPPO1, 2, 3 and 4 are representative of DJF, SON, MAM, and JJA, respectively (see Table 1). BC in the lower troposphere over the Pacific Ocean is mostly controlled by either emissions from sources in remaining regions (e.g., ships) or the closest upwind source regions like Australia, South America and East 


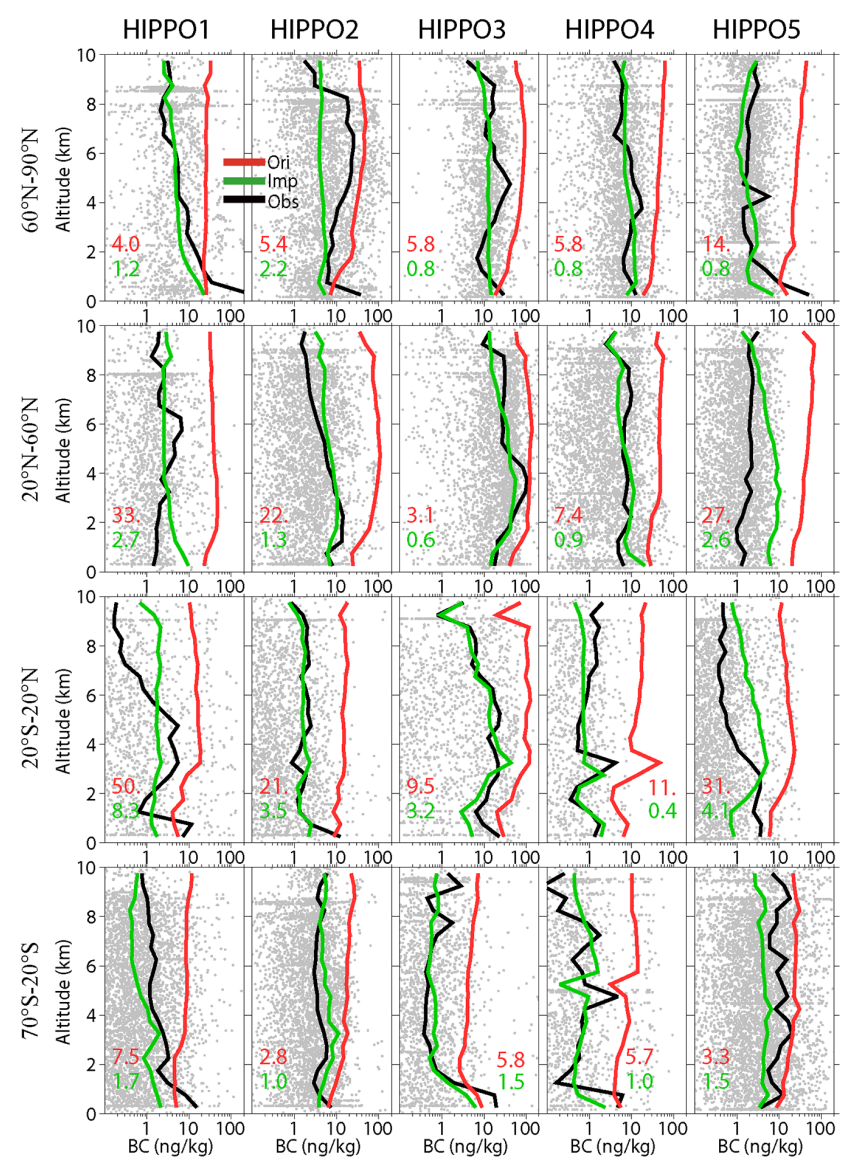

Figure 4. Vertical profiles of simulated and observed BC mass mixing ratios over $0.5 \mathrm{~km}$ altitude bins along the flight tracks of HIPPO $1-5$ over the central Pacific Ocean $\left(130^{\circ} \mathrm{W}-160^{\circ} \mathrm{E}\right)$. Data are shown separately as averaged over $70-20^{\circ} \mathrm{S}, 20^{\circ} \mathrm{S}-20^{\circ} \mathrm{N}, 20$ $60^{\circ} \mathrm{N}$, and $60-90^{\circ} \mathrm{N}$. The black, red, and green lines are mean values of $\mathrm{BC}$ mixing ratios from observations, default, and improved models, respectively. The gray dots represent measured BC concentrations. The green (red) number indicates the averaged MNAE for the improved (original) model (see Eq. 3).

Asia (Fig. 5a). On the other hand, BC in the mid- and upper troposphere is influenced mostly by $\mathrm{BC}$ emissions from major source regions: East Asia, Australia, South America, Africa, and North America except Canada. East Asian BC emissions, which are mainly of anthropogenic origin, dominate BC loading over the North Pacific Ocean even though the aging of East Asian BC is fast. Also, as shown in Fig. 5b, Arctic BC is dominated by European emissions, while BC in Antarctica is dominated by South American emissions.

The relative contribution of emissions from each source region to $\mathrm{BC}$ burden over each receptor region is presented in Table 2. We add an extra receptor region, the central Pacific Ocean, defined as $60^{\circ} \mathrm{S}-58^{\circ} \mathrm{N}, 160^{\circ} \mathrm{E}-130^{\circ} \mathrm{W}$. In the central Pacific Ocean, the dominant contributor is East Asia, accounting for $26 \%$ of the burden. In the former Soviet Union, Middle Asia, and Canada, local emissions account
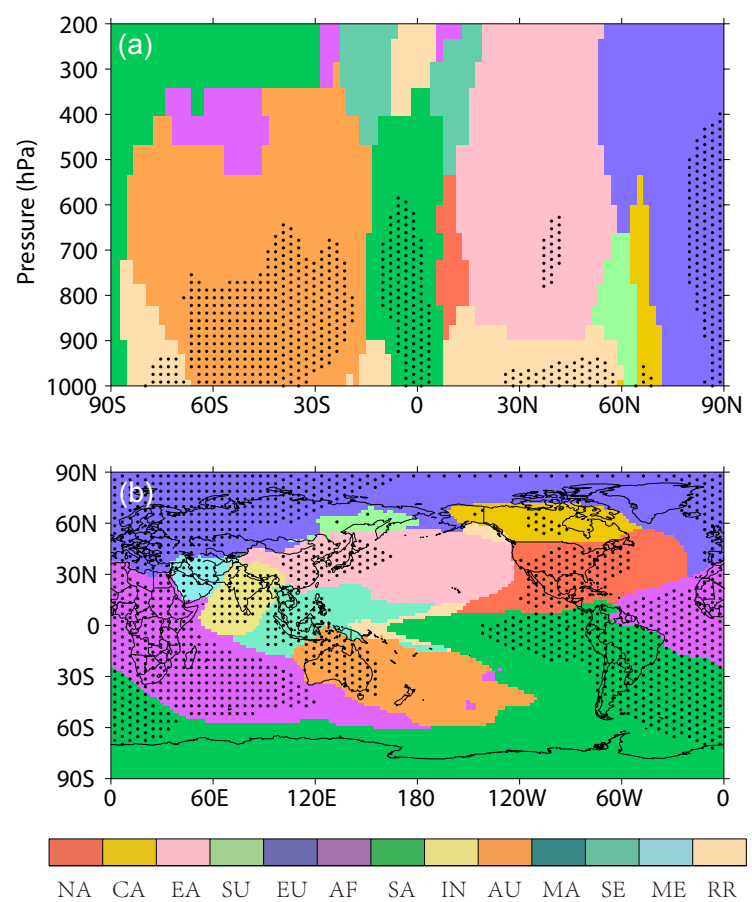

Figure 5. The most significant regional contributors to (a) zonal mean $\mathrm{BC}$ concentration over the Pacific $\left(130^{\circ} \mathrm{W}-160^{\circ} \mathrm{E}\right)$, and (b) the column burden of BC in the troposphere $(200-1000 \mathrm{hPa}$, 2009-2011 average). Dotted area represents where the most significant contributor accounts for more than $50 \%$ of the total BC.

for no more than $50 \%$ of the $\mathrm{BC}$ burden, whereas Europe contributes 44,43 , and $14 \%$ to these countries' burdens, respectively. $\mathrm{BC}$ over other regions is dominated by local sources. For example, local sources are responsible for 89 , 77 , and $73 \%$ of the BC burden in India, East Asia and North America. Thus, controlling local anthropogenic sources is expected to have the largest impact on $\mathrm{BC}$ burdens in these regions.

Table 3 compares the annual mean (2009-2011 average) dry-deposition flux, wet-deposition flux, burden, and lifetime for $\mathrm{BC}$ emitted from different source regions. The lifetime of $\mathrm{BC}$ estimated by the improved model is 4.9 days. This lifetime is quite similar to that from recent studies (Wang et al., 2014 and Hodnebrog et al., 2014). They modify model scavenging processes to better reproduce HIPPO observations and find that $\mathrm{BC}$ lifetimes are shortened from 5.9 to 4.2 days, and from 6.3 to 3.9 days. In addition, Samset et al. (2014) find that while the lifetime of $\mathrm{BC}$ is $6.8 \pm 1.8$ days averaged over 13 AeroCom models, the models with a lifetime of less than 5 days best match HIPPO observations. Our result is in accordance with their conclusions and is lower than the BC lifetime of 6.1 days estimated by Bond et al. (2013).

Table 3 also shows that the lifetime of $\mathrm{BC}$ varies significantly by source region, ranging from 2 to 10 days. Regional variation in the lifetime of $\mathrm{BC}$ is likely caused by differences in wet scavenging, which depend on precipitation patterns 
Table 2. Relative contribution (\%) of emissions from 13 source regions to BC burden in the troposphere (200-1000 hPa) over local and nonlocal receptors and to areas over the central Pacific Ocean (PO; $160^{\circ} \mathrm{E}-130^{\circ} \mathrm{W}$ and $\left.60^{\circ} \mathrm{S}-58^{\circ} \mathrm{N}\right)$. Relative contributions that are more than $10 \%$ are highlighted in bold.

\begin{tabular}{|c|c|c|c|c|c|c|c|c|c|c|c|c|c|c|c|}
\hline \multicolumn{16}{|c|}{ Receptor } \\
\hline & & $\mathrm{CA}$ & SU & EU & MA & EA & $\mathrm{ME}$ & NA & SE & IN & $\mathrm{AF}$ & SA & $\mathrm{AU}$ & RR & $\mathrm{PO}$ \\
\hline \multirow{13}{*}{ 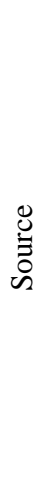 } & $\mathrm{CA}$ & 48.5 & 1.6 & 1.3 & 0.9 & 0.1 & 0.3 & 5.2 & 0.0 & 0.0 & 0.1 & 0.0 & 0.0 & 1.4 & 1.5 \\
\hline & SU & 5.4 & 30.3 & 1.2 & 7.2 & 1.9 & 0.4 & 1.0 & 0.1 & 0.1 & 0.0 & 0.0 & 0.0 & 1.8 & 5.9 \\
\hline & EU & 13.7 & 43.6 & 82.4 & 42.8 & 3.8 & 15.2 & 3.2 & 0.3 & 1.1 & 4.5 & 0.3 & 0.0 & 7.0 & 7.9 \\
\hline & MA & 0.8 & 4.2 & 0.6 & 18.1 & 1.0 & 1.3 & 0.3 & 0.1 & 0.3 & 0.0 & 0.0 & 0.0 & 0.3 & 0.9 \\
\hline & EA & 6.2 & 9.5 & 0.5 & 1.8 & 76.9 & 0.5 & 4.6 & 6.2 & 0.4 & 0.1 & 0.0 & 0.1 & 9.6 & 26.3 \\
\hline & ME & 2.4 & 4.1 & 3.7 & 20.3 & 2.3 & 53.3 & 1.5 & 1.1 & 4.7 & 3.2 & 0.2 & 0.1 & 2.5 & 3.8 \\
\hline & NA & 10.6 & 1.9 & 2.4 & 1.8 & 0.4 & 1.4 & 72.9 & 0.2 & 0.3 & 0.6 & 0.4 & 0.0 & 4.8 & 4.2 \\
\hline & SE & 0.6 & 0.2 & 0.1 & 0.1 & 5.0 & 0.2 & 1.3 & 60.1 & 0.9 & 0.1 & 0.1 & 3.3 & 6.0 & 8.6 \\
\hline & IN & 0.8 & 0.3 & 0.2 & 0.9 & 6.8 & 4.9 & 1.2 & 22.1 & 89.1 & 0.8 & 0.0 & 0.1 & 9.8 & 5.4 \\
\hline & $\mathrm{AF}$ & 0.8 & 1.2 & 5.2 & 4.4 & 1.1 & 20.8 & 2.3 & 1.6 & 2.7 & 88.5 & 9.8 & 9.8 & 35.9 & 7.4 \\
\hline & SA & 0.1 & 0.1 & 0.0 & 0.0 & 0.0 & 0.1 & 1.5 & 0.2 & 0.0 & 1.2 & 88.2 & 5.7 & 11.6 & 6.5 \\
\hline & $\mathrm{AU}$ & 0.0 & 0.0 & 0.0 & 0.0 & 0.0 & 0.0 & 0.0 & 5.3 & 0.0 & 0.0 & 0.2 & 79.1 & 3.4 & 7.0 \\
\hline & RR & 9.9 & 3.1 & 2.4 & 1.7 & 0.7 & 1.5 & 5.0 & 2.8 & 0.5 & 0.8 & 0.8 & 1.8 & 6.0 & 14.7 \\
\hline
\end{tabular}

and the hygroscopicity of BC-containing particles. The lifetimes of BC emitted from the former Soviet Union (4.4 days), East Asia (2.2 days), North America (3.7 days) and Southeast Asia (3.1 days) are shorter than the corresponding global average. Given the wide range of $\mathrm{BC}$ lifetime by source region, the relative contribution of different regions to burdens is not well characterized by the relative rates of emissions. For example, although East Asia emits the largest amount of BC, its lifetime is the shortest ( $\sim 2$ days). This means that the contribution of East Asian emissions to the global BC burden is only one third of that of the second leading source region (Africa). Using a different model and a rough division of source regions, Wang et al. (2014) also find that the lifetimes of East Asian (2.8 days), Southeast Asian (2.1 days), and American BC emissions (3.0 days) are shorter than the global average lifetime (4.7 days).

\section{Dependence of $\mathrm{BC}$ lifetime on aging timescale}

In this section, we further investigate the dependence of lifetime (derived by the annual mean burden and removal flux) on aging timescale for $\mathrm{BC}$ emitted from different source regions. As shown in Fig. 6, the lifetime of BC originating from different regions increases approximately linearly with aging timescale. Although there is variation in the $y$ intercepts for curves of lifetime vs. aging timescale, slopes are quite similar. In an effort to understand the drivers of the relationship between lifetime $T(\mathrm{~h})$ and aging timescale $\tau(\mathrm{h})$, we derive a theoretical description here. Taking the global atmosphere as a box, the mass balance for $B_{1}$ (annual mean hydrophobic BC burden; unit: $\mathrm{kg}$ ) and $B_{2}$ (annual mean hydrophilic $\mathrm{BC}$ burden; unit: $\mathrm{kg}$ ) are

$$
\begin{aligned}
& \frac{\mathrm{d} B_{1}}{\mathrm{~d} t}=(1-\alpha) E-\frac{B_{1}}{\tau}-K_{\mathrm{D}} B_{1}, \\
& \frac{\mathrm{d} B_{2}}{\mathrm{~d} t}=\alpha E+\frac{B_{1}}{\tau}-\left(K_{\mathrm{D}}+K_{\mathrm{W}}\right) B_{2},
\end{aligned}
$$

where $\alpha$ is the fraction of $\mathrm{BC}$ emitted that is hydrophilic, $E\left(\mathrm{~kg} \mathrm{hr}^{-1}\right)$ is the annual mean emission rate, and $K_{\mathrm{D}}$ and $K_{\mathrm{W}}$ are the first-order dry- and wet-deposition coefficients $\left(\mathrm{hr}^{-1}\right)$, respectively. $K_{\mathrm{W}}$ accounts for both precipitation intensity and scavenging efficiency.

Assuming that both hydrophilic and hydrophobic BC is in steady state, we derive the lifetime of $\mathrm{BC}$ as

$T=\frac{B_{1}+B_{2}}{E}=\frac{\left((1-\alpha) K_{\mathrm{W}}+K_{\mathrm{D}}\right) \tau+1}{\left(1+K_{\mathrm{D}} \tau\right)\left(K_{\mathrm{D}}+K_{\mathrm{W}}\right)}$.

If further assuming that $K_{\mathrm{D}}$ and $K_{\mathrm{W}}$ are not dependent on $\tau$, we then derive the slope $S$ (Eq. 7) and intercept (Eq. 8) of the $T-\tau$ curve:

$S=\frac{\mathrm{d} T}{\mathrm{~d} \tau}=\frac{(1-\alpha) K_{\mathrm{W}}}{\left(K_{\mathrm{D}}+K_{\mathrm{W}}\right)\left(1+K_{\mathrm{D}} \tau\right)^{2}}$

$T(\tau=0)=\frac{1}{K_{\mathrm{W}}+K_{\mathrm{D}}}$.

The slope $S$ represents the sensitivity of BC lifetime to aging timescale, which is a function of wet- and dry-deposition coefficients of $\mathrm{BC}$, and the fraction of $\mathrm{BC}$ emitted that is hydrophilic. Given Equation 7, if $\alpha=1$ then $S=0$, implying that all $\mathrm{BC}$ is aged and therefore hydrophilic as emitted. If $K_{\mathrm{D}}=0$ then $S=1-\alpha$. Therefore, if $K_{\mathrm{D}}$ is negligible, the lifetime of $\mathrm{BC}$ will be linearly related to aging timescale. In addition, lower fractions of hydrophilic $\mathrm{BC}$ in emissions $(\alpha)$ will lead to larger sensitivities of BC lifetime to aging 
Table 3. Global budget for BC emitted from 13 source regions (2009-2011 average) using the optimized aging timescale for each region.

\begin{tabular}{|c|c|c|c|c|c|c|c|c|c|c|c|c|c|c|}
\hline & CA & SU & EU & MA & EA & $\mathrm{ME}$ & NA & SE & IN & $\mathrm{AF}$ & SA & $\mathrm{AU}$ & $\mathrm{RR}$ & All \\
\hline Emission $\left(\mathrm{Tg} \mathrm{yr}^{-1}\right)$ & 0.07 & 0.14 & 0.46 & 0.03 & 1.93 & 0.17 & 0.35 & 0.55 & 0.75 & 1.62 & 0.64 & 0.15 & 0.12 & 6.98 \\
\hline Dry deposition $\left(\mathrm{Tg} \mathrm{yr}^{-1}\right)$ & 0.01 & 0.02 & 0.11 & 0.01 & 0.23 & 0.03 & 0.05 & 0.04 & 0.14 & 0.24 & 0.09 & 0.02 & 0.02 & 1.00 \\
\hline Wet deposition $\left(\mathrm{Tg} \mathrm{yr}^{-1}\right)$ & 0.06 & 0.12 & 0.35 & 0.02 & 1.70 & 0.14 & 0.30 & 0.51 & 0.61 & 1.38 & 0.55 & 0.13 & 0.10 & 5.98 \\
\hline Burden $(\mathrm{Gg})$ & 1.2 & 1.7 & 9.0 & 0.6 & 11.4 & 4.3 & 3.6 & 4.7 & 10.7 & 31.6 & 9.1 & 2.2 & 2.8 & 92.8 \\
\hline Lifetime (d) & 6.3 & 4.4 & 7.1 & 7.1 & 2.2 & 9.3 & 3.7 & 3.1 & 5.2 & 7.1 & 5.2 & 5.3 & 8.4 & 4.9 \\
\hline
\end{tabular}

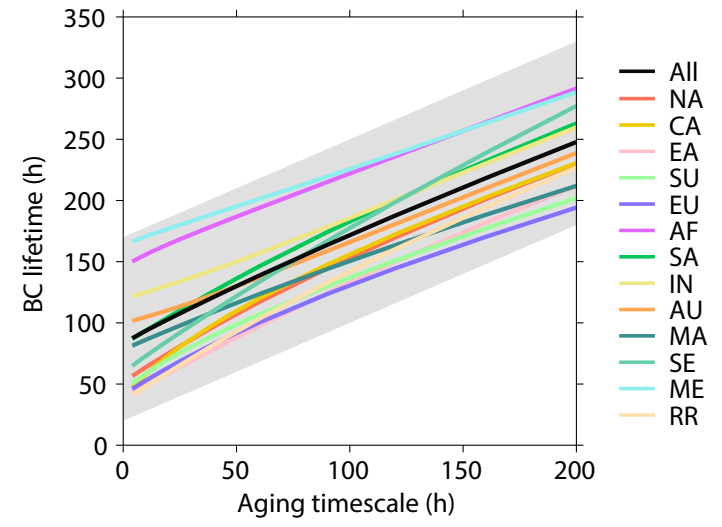

Figure 6. The lifetime of global BC (black) and tagged BC emitted from 13 source regions (colors) as a function of aging timescale. The top and bottom edges of the gray shading indicate a slope of 0.8 .

timescale $(S)$. In MOZART- $4, \alpha$ is assumed to be 0.2 for all emission sources. So if $K_{\mathrm{D}}$ is negligible, the theoretical slope of the $T-\tau$ curve is $1-0.2=0.8$, which is very close to the curve for untagged BC (black line) in Fig. 6.

The intercepts of $T-\tau$ curves represent the lifetime of BC when the aging process is extremely fast (i.e., low values of aging timescale) such that all emitted $\mathrm{BC}$ can be regarded as being hydrophilic. As shown by Eq. (8), the intercept is a function of the local wet-deposition coefficient and drydeposition coefficient. Intercepts of the $T-\tau$ curves vary by source, ranging from 40 to $170 \mathrm{~h}$. BC emitted in the Middle East, Africa, Canada, Australia, and South America has a larger intercept than the untagged $\mathrm{BC}$ because the climate in these regions lacks precipitation. The Middle East is dry and lacks precipitation in general, and emissions from Africa, Canada, and Australia are mainly from biomass burning activities that usually occur during their dry seasons.

It should be noted that in our derivation of Eqs. (6) and (8), we assume that $K_{\mathrm{D}}$ and $K_{\mathrm{W}}$ are independent of $\tau$. In reality, however, $K_{\mathrm{D}}$ and $K_{\mathrm{W}}$ can depend on $\tau$. For example, as aging timescale increases, $\mathrm{BC}$ has a longer lifetime and is more likely to encounter precipitation in regions farther away from the source. Nonetheless, the discussion above helps elucidate that the dependence of lifetime on aging timescale is determined by the fraction of emitted $\mathrm{BC}$ that is hydrophilic, and the factors that influence dry and wet deposition (e.g., precipitation).

Since the aging timescale varies by region and season, the common practice in modeling of setting a fixed global uniform aging rate may lead to a significant misrepresentation of $\mathrm{BC}$ lifetime and burden. Employing realistic aging timescales is especially important for the regions shown in Fig. 6 with the highest slopes and lowest intercepts; changes in aging timescale would lead to the largest relative changes in BC lifetime in these regions. For instance, for Southeast Asia, increasing the aging timescale of $\mathrm{BC}$ from 0 to $60 \mathrm{~h}$ nearly doubles its lifetime.

Policies that control $\mathrm{SO}_{2}$ and other soluble compounds may slow $\mathrm{BC}$ aging, increase the lifetime of $\mathrm{BC}$, and partially offset efforts made on BC mitigation. For example, as indicated by a chamber study, employing aftertreatment technologies such as oxidation catalysts in combustion systems can reduce emissions of volatile organic compounds and the formation of secondary organic aerosols (SOAs) that could internally mix with $\mathrm{BC}$, ultimately slowing the aging of $\mathrm{BC}$ (Tritscher et al., 2011). Thus, policies for protecting human health that target reductions in emissions of only fine soluble particulate matter (i.e., sulfate, nitrate and SOA) could increase the $\mathrm{BC}$ burden through increases in aging timescale and potentially enhances its positive radiative forcing.

\section{Caveats}

We note that there are multiple limitations to our approach. Firstly, we assume that model parameterizations of wet and dry deposition, precipitation, transport, and emissions are realistic, even though these processes also affect BC distributions and have uncertainties (Vignati et al., 2010; Fan et al., 2012). Consequently, the optimized aging timescales may partially counter biases in these processes (i.e., other than aging) and may vary according to the model used. For example, as model resolution increases, aerosol-cloud interactions in climate models can be better resolved, which can improve the simulation of BC transport (Ma et al., 2013b, 2014). Therefore, the optimized aging timescales might change if models with different cloud schemes or spatial resolutions are used. Secondly, due to limitations in computing resources, we carry out simulations assuming 13 discrete values for aging timescale. Optimized aging timescale could have been 
more precisely determined with more simulations. Thirdly, the optimized aging results may somewhat depend on the error matrix chosen. We conduct additional simulations with different error matrices (see Tables S2, S3). The results are overall similar, but in some cases moderate differences are found. Fourthly, the computed optimized aging rate is more accurate for tracers (i.e., source regions) with larger emissions and in closer proximity to the Pacific Ocean (e.g., East Asia). This is because modeled BC concentrations over the Pacific (i.e., the location of HIPPO observations) for each latitude and longitude bin are typically dominated by only a few source regions, and the sensitivity of MNAE on each regional BC tracer is different (see Fig. S5). For some source regions, observations in other remote regions would provide a better constraint for optimizing the aging timescale in the model. More specifically, aircraft observations over the Atlantic Ocean could better constrain aging timescales for BC emitted from Africa and South America. As new observations become available, this study could be repeated to more accurately optimize the aging timescale for source regions with lower relative contributions to $\mathrm{BC}$ over the Pacific (e.g., Middle Asia). The goal of the optimization presented here is not to provide precise aging timescales that can be directly used in models, since models differ significantly in their parameterizations of physical and chemical processes, particularly the wet scavenging. Also, $\mathrm{BC}$ aging includes complicated chemistry and physics but is simplified in our modeling as a first-order conversion from hydrophobic to hydrophilic BC. Nevertheless, this study proposes a useful method to utilize all HIPPO observations and explore the spatiotemporal pattern of $\mathrm{BC}$ aging timescales globally.

\section{Conclusions}

In this study, we tag BC emitted from 13 regions around the globe and conduct a set of sensitivity simulations to investigate how different aging timescales affect spatial distributions and source-receptor relationships for $\mathrm{BC}$ in a global chemical transport model, MOZART-4. We find that BC burden and source-receptor relationships are remarkably sensitive to the assumed aging timescale in the model; this motivates our use of HIPPO observations to optimize the BC aging timescale by minimizing model-measurement differences. Physically based dry- and wet-deposition schemes and optimized aging timescales for different regions are employed in MOZART-4, which significantly improves the model's performance over the Pacific Ocean relative to the default model; the campaign-averaged mean normalized absolute error is reduced by a factor of $4-10$. The optimized aging timescales vary greatly by source region and season. In the Northern Hemisphere, we find that the aging timescale for $\mathrm{BC}$ emitted in mid- and low-latitude locations is in general less than half a day, whereas that for $\mathrm{BC}$ emitted from high-latitude locations in most seasons (i.e., spring, fall, and winter) is 4-8 days.

Using the improved model, we find that the dominant contributors to $\mathrm{BC}$ in the lower troposphere over the central $\mathrm{Pa}$ cific Ocean are local sources (i.e., ship emissions), Australia, South America and East Asia. For the mid- and upper troposphere over the Pacific Ocean, the dominant sources are East Asia, Australia, South America, Africa, and North America. East Asian emissions contribute the most $(26 \%)$ to the total burden of tropospheric BC over the Pacific Ocean. We also find that $\mathrm{BC}$ emitted from different source regions has distinct atmospheric lifetimes, suggesting that comparing only emissions of different regions does not directly predict their contribution to burden and therefore climate consequences. The lifetimes of BC emitted from East Asia, Southeast Asia, North America, and the former Soviet Union are 2.2, 3.2, 3.8, and 4.4 days respectively, shorter than 4.9 days, the global average lifetime.

Using model sensitivity simulations we determine the sensitivity of BC lifetime to aging timescale for emissions from each source region. The lifetime-aging-timescale relationship is nearly linear for most regions. The sensitivity is influenced by wet- and dry-deposition rates and more importantly by a parameter that describes the fraction of $\mathrm{BC}$ emissions that are emitted directly as hydrophilic.

Future observations that speciate coatings on $\mathrm{BC}$ and measure hygroscopicity of both freshly emitted and aged BC in different regions and seasons are needed to further constrain aging timescales and understand the physics and chemistry of the aging process. The lifetime of $\mathrm{BC}$ determines its global reach and consequently its radiative forcing on the climate system. BC with slow aging timescales and long lifetimes can influence the climate in remote areas substantially (e.g., over the oceans and the Arctic). In principle, the estimated climate impacts of $\mathrm{BC}$ emitted from different regions rely on the representation of particles' hygroscopicity and the assumptions about aging timescales. Our study highlights the importance of accurately representing aging processes in models and parameterizing aging timescales differently in different regions and seasons.

We recommend that future inter-model comparisons like AeroCom use tagging techniques to compare model estimates of the lifetimes of $\mathrm{BC}$ emitted from different regions. The tracer tagging technique utilized here can also be used to estimate regional source contributions to $\mathrm{BC}$ observed in future aircraft campaigns, to help choose locations for future campaigns, and to attribute discrepancies in inter-model comparisons to specific source regions.

The Supplement related to this article is available online at doi:10.5194/acp-15-11521-2015-supplement. 
Acknowledgements. We thank Xiaoyuan Li, Cenlin He, Kan Yi, Wei Tao, Jing Meng, Huizhong Shen, Maowei Wu, Zhaoyi Shen, Kan Chen and Yan Xia for their helpful contributions and suggestions to this study. We also thank Huisheng Bian and the other three reviewers for their constructive comments and suggestions. This work was supported by funding from the National Natural Science Foundation of China under awards 41222011, 41390241 and 41130754, the Research Project of the Chinese Ministry of Education no. 113001A, the undergraduate student research training program, and the 111 Project (B14001).

Edited by: M. Shiraiwa

\section{References}

Ban-Weiss, G. A., Cao, L., Bala, G., and Caldeira, K.: Dependence of climate forcing and response on the altitude of black carbon aerosols, Clim. Dynam., 38, 897-911, doi:10.1007/s00382-0111052-y, 2012.

Bell, M. L., Ebisu, K., Peng, R. D., Samet, J. M., and Dominici, F.: Hospital Admissions and Chemical Composition of Fine Particle Air Pollution, Am. J. Resp. Crit. Care, 179, 1115-1120, doi:10.1164/rccm.200808-1240OC, 2009.

Bian, H., Colarco, P. R., Chin, M., Chen, G., Rodriguez, J. M., Liang, Q., Blake, D., Chu, D. A., da Silva, A., Darmenov, A. S., Diskin, G., Fuelberg, H. E., Huey, G., Kondo, Y., Nielsen, J. E., Pan, X., and Wisthaler, A.: Source attributions of pollution to the Western Arctic during the NASA ARCTAS field campaign, Atmos. Chem. Phys., 13, 4707-4721, doi:10.5194/acp-13-47072013, 2013.

Bollasina, M. A., Ming, Y., and Ramaswamy, V.: Anthropogenic Aerosols and the Weakening of the South Asian Summer Monsoon, Science, 334, 502-505, doi:10.1126/science.1204994, 2011.

Bollasina, M. A., Ming, Y., Ramaswamy, V., Schwarzkopf, M. D., and Naik, V.: Contribution of local and remote anthropogenic aerosols to the twentieth century weakening of the South Asian Monsoon, Geophys. Res. Lett., 41, 680-687, doi:10.1002/2013g1058183, 2014.

Bond, T. C., Doherty, S. J., Fahey, D. W., Forster, P. M., Berntsen, T., DeAngelo, B. J., Flanner, M. G., Ghan, S., Karcher, B., Koch, D., Kinne, S., Kondo, Y., Quinn, P. K., Sarofim, M. C., Schultz, M. G., Schulz, M., Venkataraman, C., Zhang, H., Zhang, S., Bellouin, N., Guttikunda, S. K., Hopke, P. K., Jacobson, M. Z., Kaiser, J. W., Klimont, Z., Lohmann, U., Schwarz, J. P., Shindell, D., Storelvmo, T., Warren, S. G., and Zender, C. S.: Bounding the role of black carbon in the climate system: A scientific assessment, J. Geophys. Res.-Atmos., 118, 5380-5552, doi:10.1002/Jgrd.50171, 2013.

Bourgeois, Q. and Bey, I.: Pollution transport efficiency toward the Arctic: Sensitivity to aerosol scavenging and source regions, J. Geophys. Res., 116, D08213, doi:10.1029/2010jd015096, 2011.

Cheng, Y. F., Su, H., Rose, D., Gunthe, S. S., Berghof, M., Wehner, B., Achtert, P., Nowak, A., Takegawa, N., Kondo, Y., Shiraiwa, M., Gong, Y. G., Shao, M., Hu, M., Zhu, T., Zhang, Y. H., Carmichael, G. R., Wiedensohler, A., Andreae, M. O., and Pöschl, U.: Size-resolved measurement of the mixing state of soot in the megacity Beijing, China: diurnal cycle, aging and parameterization, Atmos. Chem. Phys., 12, 4477-4491, doi:10.5194/acp-12-4477-2012, 2012.

China, S., Scarnato, B., Owen, R. C., Zhang, B., Ampadu, M. T., Kumar, S., Dzepina, K., Dziobak, M. P., Fialho, P., Perlinger, J. A., Hueber, J., Helmig, D., Mazzoleni, L. R., and Mazzoleni, C.: Morphology and mixing state of aged soot particles at a remote marine free troposphere site: Implications for optical properties, Geophys. Res. Lett., 42, GL062404, doi:10.1002/2014g1062404, 2015.

Cozic, J., Verheggen, B., Mertes, S., Connolly, P., Bower, K., Petzold, A., Baltensperger, U., and Weingartner, E.: Scavenging of black carbon in mixed phase clouds at the high alpine site Jungfraujoch, Atmos. Chem. Phys., 7, 1797-1807, doi:10.5194/acp-7-1797-2007, 2007.

Croft, B., Lohmann, U., Martin, R. V., Stier, P., Wurzler, S., Feichter, J., Hoose, C., Heikkilä, U., van Donkelaar, A., and Ferrachat, S.: Influences of in-cloud aerosol scavenging parameterizations on aerosol concentrations and wet deposition in ECHAM5-HAM, Atmos. Chem. Phys., 10, 1511-1543, doi:10.5194/acp-10-1511-2010, 2010.

Croft, B., Pierce, J. R., Martin, R. V., Hoose, C., and Lohmann, U.: Uncertainty associated with convective wet removal of entrained aerosols in a global climate model, Atmos. Chem. Phys., 12, 10725-10748, doi:10.5194/acp-12-10725-2012, 2012.

Emmons, L. K., Walters, S., Hess, P. G., Lamarque, J.-F., Pfister, G. G., Fillmore, D., Granier, C., Guenther, A., K innison, D., Laepple, T., Orlando, J., Tie, X., Tyndall, G., Wiedinmyer, C., Baughcum, S. L., and Kloster, S.: Description and evaluation of the Model for Ozone and Related chemical Tracers, version 4 (MOZART-4), Geosci. Model Dev., 3, 43-67, doi:10.5194/gmd3-43-2010, 2010.

Evan, A. T., Kossin, J. P., Chung, C., and Ramanathan, V.: Arabian Sea tropical cyclones intensified by emissions of black carbon and other aerosols, Nature, 479, 94-97, doi:10.1038/Nature10552, 2011.

Fan, S. M., Schwarz, J. P., Liu, J., Fahey, D. W., Ginoux, P., Horowitz, L. W., Levy, H., Ming, Y., and Spackman, J. R.: Inferring ice formation processes from global-scale black carbon profiles observed in the remote atmosphere and model simulations, J. Geophys. Res.-Atmos., 117, D23205, doi:10.1029/2012jd018126, 2012.

Feng, H.: A 3-mode parameterization of below-cloud scavenging of aerosols for use in atmospheric dispersion models, Atmos. Environ., 41, 6808-6822, doi:10.1016/j.atmosenv.2007.04.046, 2007.

Flanner, M. G., Zender, C. S., Randerson, J. T., and Rasch, P. J.: Present-day climate forcing and response from black carbon in snow, J. Geophys. Res.-Atmos., 112, D11202, doi:10.1029/2006jd008003, 2007.

Gallagher, M. W., Nemitz, E., Dorsey, J. R., Fowler, D., Sutton, M. A., Flynn, M., and Duyzer, J.: Measurements and parameterizations of small aerosol deposition velocities to grassland, arable crops, and forest: Influence of surface roughness length on deposition, J. Geophys. Res.-Atmos., 107, 4154, doi:10.1029/2001jd000817, 2002.

Hack, J. J.: Parameterization of moist convection in the National Center for Atmospheric Research community climate model (CCM2), J. Geophys. Res.-Atmos., 99, 5551-5568, doi:10.1029/93jd03478, 1994. 
Hansen, J. and Nazarenko, L.: Soot climate forcing via snow and ice albedos, P. Natl. Acad. Sci. USA, 101, 423-428, doi:10.1073/pnas.2237157100, 2004.

He, C. L., Li, Q. B., Liou, K. N., Takano, Y., Gu, Y., Qi, L., Mao, Y. H., and Leung, L. R.: Black carbon radiative forcing over the Tibetan Plateau, Geophys. Res. Lett., 41, 7806-7813, doi:10.1002/2014g1062191, 2014.

Hodnebrog, O., Myhre, G., and Samset, B. H.: How shorter black carbon lifetime alters its climate effect, Nat. Commun., 5, 5065, doi:10.1038/Ncomms6065, 2014.

Holtslag, A. A. M. and Boville, B. A.: Local Versus Nonlocal Boundary-Layer Diffusion in a Global Climate Model, J. Climate, 6, 1825-1842, doi:10.1175/1520-0442(1993)006< 1825:Lvnbld> 2.0.Co, 1993.

Horowitz, L. W., Walters, S., Mauzerall, D. L., Emmons, L. K., Rasch, P. J., Granier, C., Tie, X. X., Lamarque, J. F., Schultz, M. G., Tyndall, G. S., Orlando, J. J., and Brasseur, G. P.: A global simulation of tropospheric ozone and related tracers: Description and evaluation of MOZART, version 2, J. Geophys. Res.-Atmos., 108, 4784, doi:10.1029/2002jd002853, 2003.

Huang, Y., Wu, S., Dubey, M. K., and French, N. H. F.: Impact of aging mechanism on model simulated carbonaceous aerosols, Atmos. Chem. Phys., 13, 6329-6343, doi:10.5194/acp-13-63292013, 2013.

IPCC: Climate Change 2013: the physical science basis, in: Contribution of Working Group I to the Fifth Assessment Report of the Intergovernmental Panel on Climate Change, edited by: Stocker, T. F., Qin, D., Plattner, G.-K., Tignor, M., Allen, S. K., Boschung, J., Nauels, A., Xia, Y., Bex, V. and Midgley, P. M., Cambridge University Press, Cambridge, United Kingdom and New York, NY, USA, 1535 pp., 2013.

Janssen, N. A. H., Hoek, G., Simic-Lawson, M., Fischer, P., van Bree, L., ten Brink, H., Keuken, M., Atkinson, R. W., Anderson, H. R., Brunekreef, B., and Cassee, F. R.: Black Carbon as an Additional Indicator of the Adverse Health Effects of Airborne Particles Compared with PM10 and PM2.5, Environ. Health Persp., 119, 1691-1699, doi:10.1289/Ehp.1003369, 2011.

Johnson, K. S., Zuberi, B., Molina, L. T., Molina, M. J., Iedema, M. J., Cowin, J. P., Gaspar, D. J., Wang, C., and Laskin, A.: Processing of soot in an urban environment: case study from the Mexico City Metropolitan Area, Atmos. Chem. Phys., 5, 3033-3043, doi:10.5194/acp-5-3033-2005, 2005.

Kaneyasu, N. and Murayama, S.: High concentrations of black carbon over middle latitudes in the North Pacific Ocean, J. Geophys. Res.-Atmos., 105, 19881-19890, 2000.

Kipling, Z., Stier, P., Schwarz, J. P., Perring, A. E., Spackman, J. R., Mann, G. W., Johnson, C. E., and Telford, P. J.: Constraints on aerosol processes in climate models from vertically-resolved aircraft observations of black carbon, Atmos. Chem. Phys., 13, 5969-5986, doi:10.5194/acp-13-5969-2013, 2013.

Koch, D. and Hansen, J.: Distant origins of Arctic black carbon: A Goddard Institute for Space Studies ModelE experiment, J. Geophys. Res.-Atmos., 110, D04204, doi:10.1029/2004jd005296, 2005.

Koch, D. and Del Genio, A. D.: Black carbon semi-direct effects on cloud cover: review and synthesis, Atmos. Chem. Phys., 10, 7685-7696, doi:10.5194/acp-10-7685-2010, 2010.

Koch, D., Schulz, M., Kinne, S., McNaughton, C., Spackman, J. R., Balkanski, Y., Bauer, S., Berntsen, T., Bond, T. C., Boucher,
O., Chin, M., Clarke, A., De Luca, N., Dentener, F., Diehl, T., Dubovik, O., Easter, R., Fahey, D. W., Feichter, J., Fillmore, D., Freitag, S., Ghan, S., Ginoux, P., Gong, S., Horowitz, L., Iversen, T., Kirkevåg, A., Klimont, Z., Kondo, Y., Krol, M., Liu, X., Miller, R., Montanaro, V., Moteki, N., Myhre, G., Penner, J. E., Perlwitz, J., Pitari, G., Reddy, S., Sahu, L., Sakamoto, H., Schuster, G., Schwarz, J. P., Seland, Ø., Stier, P., Takegawa, N., Takemura, T., Textor, C., van Aardenne, J. A., and Zhao, Y.: Evaluation of black carbon estimations in global aerosol models, Atmos. Chem. Phys., 9, 9001-9026, doi:10.5194/acp-9-9001-2009, 2009.

Kotzick, R. and Niessner, R.: The effects of aging processes on critical supersaturation ratios of ultrafine carbon aerosols, Atmos. Environ., 33, 2669-2677, doi:10.1016/S1352-2310(98)00315-X, 1999.

Kotzick, R., Panne, U., and Niessner, R.: Changes in condensation properties of ultrafine carbon particles subjected to oxidation by ozone, J. Aerosol. Sci., 28, 725-735, doi:10.1016/S00218502(96)00471-5, 1997.

Laborde, M., Crippa, M., Tritscher, T., Jurányi, Z., Decarlo, P. F., Temime-Roussel, B., Marchand, N., Eckhardt, S., Stohl, A., Baltensperger, U., Prévôt, A. S. H., Weingartner, E., and Gysel, M.: Black carbon physical properties and mixing state in the European megacity Paris, Atmos. Chem. Phys., 13, 5831-5856, doi:10.5194/acp-13-5831-2013, 2013.

Lamarque, J.-F., Bond, T. C., Eyring, V., Granier, C., Heil, A., Klimont, Z., Lee, D., Liousse, C., Mieville, A., Owen, B., Schultz, M. G., Shindell, D., Smith, S. J., Stehfest, E., Van Aardenne, J., Cooper, O. R., Kainuma, M., Mahowald, N., McConnell, J. R., Naik, V., Riahi, K., and van Vuuren, D. P.: Historical (1850-2000) gridded anthropogenic and biomass burning emissions of reactive gases and aerosols: methodology and application, Atmos. Chem. Phys., 10, 7017-7039, doi:10.5194/acp10-7017-2010, 2010.

Lammel, G. and Novakov, T.: Water Nucleation Properties of Carbon-Black and Diesel Soot Particles, Atmos. Environ., 29, 813-823, doi:10.1016/1352-2310(94)00308-8, 1995.

Lau, N. C. and Nath, M. J.: A Model Study of the Air-Sea Interaction Associated with the Climatological Aspects and Interannual Variability of the South Asian Summer Monsoon Development J. Climate, 25, 839-857, doi:10.1175/Jcli-D-11-00035.1, 2012.

Lin, S. J. and Rood, R. B.: Multidimensional flux-form semiLagrangian transport schemes, Mon. Weather Rev., 124, 20462070, doi:10.1175/1520-0493(1996)124< 2046:Mffslt> 2.0.Co, 1996.

Liu, D., Allan, J., Whitehead, J., Young, D., Flynn, M., Coe, H., McFiggans, G., Fleming, Z. L., and Bandy, B.: Ambient black carbon particle hygroscopic properties controlled by mixing state and composition, Atmos. Chem. Phys., 13, 2015-2029, doi:10.5194/acp-13-2015-2013, 2013.

Liu, J. F., Mauzerall, D. L., Horowitz, L. W., Ginoux, P., and Fiore, A. M.: Evaluating inter-continental transport of fine aerosols: (1) Methodology, global aerosol distribution and optical depth, Atmos. Environ., 43, 4327-4338, doi:10.1016/j.atmosenv.2009.03.054, 2009.

Liu, J. F., Fan, S. M., Horowitz, L. W., and Levy, H.: Evaluation of factors controlling long-range transport of black carbon to the Arctic, J. Geophys. Res.-Atmos., 116, D04307, doi:10.1029/2010jd015145, 2011. 
Liu, Y. K., Liu, J. F., and Tao, S.: Interannual variability of summertime aerosol optical depth over East Asia during 2000-2011: a potential influence from El Nino Southern Oscillation, Environ. Res. Lett., 8, 044034, doi:10.1088/1748-9326/8/4/044034, 2013.

Ma, P.-L., Gattiker, J. R., Liu, X., and Rasch, P. J.: A novel approach for determining source-receptor relationships in model simulations: a case study of black carbon transport in northern hemisphere winter, Environ. Res. Lett., 8, 024042, doi:10.1088/17489326/8/2/024042, 2013a.

Ma, P. L., Rasch, P. J., Wang, H. L., Zhang, K., Easter, R. C., Tilmes, S., Fast, J. D., Liu, X. H., Yoon, J. H., and Lamarque, J. F.: The role of circulation features on black carbon transport into the Arctic in the Community Atmosphere Model version 5 (CAM5), J. Geophys. Res.-Atmos., 118, 4657-4669, doi:10.1002/jgrd.50411, 2013b.

Ma, P.-L., Rasch, P. J., Fast, J. D., Easter, R. C., Gustafson Jr., W. I., Liu, X., Ghan, S. J., and Singh, B.: Assessing the CAM5 physics suite in the WRF-Chem model: implementation, resolution sensitivity, and a first evaluation for a regional case study, Geosci. Model Dev., 7, 755-778, doi:10.5194/gmd-7-755-2014, 2014.

Matsui, H. and Koike, M.: New source and process apportionment method using a three-dimensional chemical transport model: Process, Age, and Source region Chasing ALgorithm (PASCAL), Atmos. Environ., 55, 399-409, doi:10.1016/j.atmosenv.2012.02.080, 2012.

McMeeking, G. R., Good, N., Petters, M. D., McFiggans, G., and Coe, H.: Influences on the fraction of hydrophobic and hydrophilic black carbon in the atmosphere, Atmos. Chem. Phys., 11, 5099-5112, doi:10.5194/acp-11-5099-2011, 2011.

Ming, Y., Ramaswamy, V., and Persad, G.: Two opposing effects of absorbing aerosols on global-mean precipitation, Geophys. Res. Lett., 37, L13701, doi:10.1029/2010g1042895, 2010.

Moteki, N., Kondo, Y., Miyazaki, Y., Takegawa, N., Komazaki, Y., Kurata, G., Shirai, T., Blake, D. R., Miyakawa, T., and Koike, M.: Evolution of mixing state of black carbon particles: Aircraft measurements over the western Pacific in March 2004, Geophys. Res. Lett., 34, L11803, doi:10.1029/2006g1028943, 2007.

Oshima, N. and Koike, M.: Development of a parameterization of black carbon aging for use in general circulation models, Geosci. Model Dev., 6, 263-282, doi:10.5194/gmd-6-263-2013, 2013.

Ramanathan, V. and Carmichael, G.: Global and regional climate changes due to black carbon, Nat. Geosci., 1, 221-227, doi:10.1038/ngeo156, 2008.

Rasch, P. J., Mahowald, N. M., and Eaton, B. E.: Representations of transport, convection, and the hydrologic cycle in chemical transport models: Implications for the modeling of short-lived and soluble species, J. Geophys. Res.-Atmos., 102, 28127-28138, doi:10.1029/97jd02087, 1997.

Rasch, P. J., Barth, M. C., Kiehl, J. T., Schwartz, S. E., and Benkovitz, C. M.: A description of the global sulfur cycle and its controlling processes in the National Center for Atmospheric Research Community Climate Model, Version 3, J. Geophys. Res.Atmos., 105, 1367-1385, doi:10.1029/1999jd900777, 2000.

Riemer, N., Vogel, H., and Vogel, B.: Soot aging time scales in polluted regions during day and night, Atmos. Chem. Phys., 4, 1885-1893, doi:10.5194/acp-4-1885-2004, 2004.

Riemer, N., West, M., Zaveri, R., and Easter, R.: Estimating black carbon aging time-scales with a particle-resolved aerosol model,
J. Aerosol Sci., 41, 143-158, doi:10.1016/j.jaerosci.2009.08.009, 2010.

Saikawa, E., Naik, V., Horowitz, L. W., Liu, J. F., and Mauzerall, D. L.: Present and potential future contributions of sulfate, black and organic carbon aerosols from China to global air quality, premature mortality and, radiative forcing, Atmos. Environ., 43, 28142822, doi:10.1016/j.atmosenv.2009.02.017, 2009.

Samset, B. H. and Myhre, G.: Vertical dependence of black carbon, sulphate and biomass burning aerosol radiative forcing, Geophys. Res. Lett., 38, L24802, doi:10.1029/2011g1049697, 2011.

Samset, B. H. and Myhre, G.: Climate response to externally mixed black carbon as a function of altitude, J.f Geophy. Res.-Atmos., 120, JD022849, doi:10.1002/2014jd022849, 2015.

Samset, B. H., Myhre, G., Schulz, M., Balkanski, Y., Bauer, S., Berntsen, T. K., Bian, H., Bellouin, N., Diehl, T., Easter, R. C., Ghan, S. J., Iversen, T., Kinne, S., Kirkevåg, A., Lamarque, J.F., Lin, G., Liu, X., Penner, J. E., Seland, Ø., Skeie, R. B., Stier, P., Takemura, T., Tsigaridis, K., and Zhang, K.: Black carbon vertical profiles s trongly affect its radiative forcing uncertainty, Atmos. Chem. Phys., 13, 2423-2434, doi:10.5194/acp-13-24232013, 2013.

Samset, B. H., Myhre, G., Herber, A., Kondo, Y., Li, S.-M., Moteki, N., Koike, M., Oshima, N., Schwarz, J. P., Balkanski, Y., Bauer, S. E., Bellouin, N., Berntsen, T. K., Bian, H., Chin, M., Diehl, T., Easter, R. C., Ghan, S. J., Iversen, T., Kirkevåg, A., Lamarque, J.-F., Lin, G., Liu, X., Penner, J. E., Schulz, M., Seland, Ø., Skeie, R. B., Stier, P., Takemura, T., Tsigaridis, K., and Zhang, $\mathrm{K}$.: Modelled black carbon radiative forcing and atmospheric lifetime in AeroCom Phase II constrained by aircraft observations, Atmos. Chem. Phys., 14, 12465-12477, doi:10.5194/acp14-12465-2014, 2014.

Satheesh, S. K.: Aerosol radiative forcing over land: effect of surface and cloud reflection, Ann. Geophys., 20, 2105-2109, 2002, http://www.ann-geophys.net/20/2105/2002/.

Schwarz, J. P., Gao, R. S., Fahey, D. W., Thomson, D. S., Watts, L. A., Wilson, J. C., Reeves, J. M., Darbeheshti, M., Baumgardner, D. G., Kok, G. L., Chung, S. H., Schulz, M., Hendricks, J., Lauer, A., Karcher, B., Slowik, J. G., Rosenlof, K. H., Thompson, T. L., Langford, A. O., Loewenstein, M., and Aikin, K. C.: Single-particle measurements of midlatitude black carbon and light-scattering aerosols from the boundary layer to the lower stratosphere, J. Geophys. Res.-Atmos., 111, D16207, doi:10.1029/2006jd007076, 2006.

Schwarz, J. P., Spackman, J. R., Fahey, D. W., Gao, R. S., Lohmann, U., Stier, P., Watts, L. A., Thomson, D. S., Lack, D. A., Pfister, L., Mahoney, M. J., Baumgardner, D., Wilson, J. C., and Reeves, J. M.: Coatings and their enhancement of black carbon light absorption in the tropical atmosphere, J. Geophys. Res.-Atmos., 113, D03203, doi:10.1029/2007jd009042, 2008.

Schwarz, J. P., Spackman, J. R., Gao, R. S., Watts, L. A., Stier, P., Schulz, M., Davis, S. M., Wofsy, S. C., and Fahey, D. W.: Global-scale black carbon profiles observed in the remote atmosphere and compared to models, Geophys. Res. Lett., 37, L18812, doi:10.1029/2010g1044372, 2010.

Schwarz, J. P., Samset, B. H., Perring, A. E., Spackman, J. R., Gao, R. S., Stier, P., Schulz, M., Moore, F. L., Ray, E. A., and Fahey, D. W.: Global-scale seasonally resolved black carbon vertical profiles over the Pacific, Geophys. Res. Lett., 40, GL057775, doi:10.1002/2013g1057775, 2013. 
Shen, Z., Liu, J., Horowitz, L. W., Henze, D. K., Fan, S., H., Levy II, Mauzerall, D. L., Lin, J.-T., and Tao, S.: Analysis of transpacific transport of black carbon during HIPPO-3: implications for black carbon aging, Atmos. Chem. Phys., 14, 6315-6327, doi:10.5194/acp-14-6315-2014, 2014.

Shindell, D. T., Chin, M., Dentener, F., Doherty, R. M., Faluvegi, G., Fiore, A. M., Hess, P., Koch, D. M., MacKenzie, I. A., Sanderson, M. G., Schultz, M. G., Schulz, M., Stevenson, D. S., Teich, H., Textor, C., Wild, O., Bergmann, D. J., Bey, I., Bian, H., Cuvelier, C., Duncan, B. N., Folberth, G., Horowitz, L. W., Jonson, J., Kaminski, J. W., Marmer, E., Park, R., Pringle, K. J., Schroeder, S., Szopa, S., Takemura, T., Zeng, G., Keating, T. J., and Zuber, A.: A multi-model assessment of pollution transport to the Arctic, Atmos. Chem. Phys., 8, 5353-5372, doi:10.5194/acp-85353-2008, 2008.

Textor, C., Schulz, M., Guibert, S., Kinne, S., Balkanski, Y., Bauer, S., Berntsen, T., Berglen, T., Boucher, O., Chin, M., Dentener, F., Diehl, T., Feichter, J., Fillmore, D., Ginoux, P., Gong, S., Grini, A., Hendricks, J., Horowitz, L., Huang, P., Isaksen, I. S. A., Iversen, T., Kloster, S., Koch, D., Kirkevåg, A., Kristjansson, J. E., Krol, M., Lauer, A., Lamarque, J. F., Liu, X., Montanaro, V., Myhre, G., Penner, J. E., Pitari, G., Reddy, M. S., Seland, Ø., Stier, P., Takemura, T., and Tie, X.: The effect of harmonized emissions on aerosol properties in global models an AeroCom experiment, Atmos. Chem. Phys., 7, 4489-4501, doi:10.5194/acp-7-4489-2007, 2007.

Tritscher, T., Juranyi, Z., Martin, M., Chirico, R., Gysel, M., Heringa, M. F., DeCarlo, P. F., Sierau, B., Prevot, A. S. H., Weingartner, E., and Baltensperger, U.: Changes of hygroscopicity and morphology during ageing of diesel soot, Environ Res Lett, 6, 034026, doi:10.1088/1748-9326/6/3/034026, 2011.

van der Werf, G. R., Randerson, J. T., Giglio, L., Collatz, G. J., Mu, M., Kasibhatla, P. S., Morton, D. C., DeFries, R. S., Jin, Y., and van Leeuwen, T. T.: Global fire emissions and the contribution of deforestation, savanna, forest, agricultural, and peat fires (19972009), Atmos. Chem. Phys., 10, 11707-11735, doi:10.5194/acp10-11707-2010, 2010.
Vignati, E., Karl, M., Krol, M., Wilson, J., Stier, P., and Cavalli, F.: Sources of uncertainties in modelling black carbon at the global scale, Atmos. Chem. Phys., 10, 2595-2611, doi:10.5194/acp-102595-2010, 2010.

Wang, H. L., Rasch, P. J., Easter, R. C., Singh, B., Zhang, R. D., Ma, P. L., Qian, Y., Ghan, S. J., and Beagley, N.: Using an explicit emission tagging method in global modeling of source-receptor relationships for black carbon in the Arctic: Variations, sources, and transport pathways, J. Geophys. Res.-Atmos., 119, 1288812909, doi:10.1002/2014jd022297, 2014.

Wang, Q., Jacob, D. J., Fisher, J. A., Mao, J., Leibensperger, E. M., Carouge, C. C., Le Sager, P., Kondo, Y., Jimenez, J. L., Cubison, M. J., and Doherty, S. J.: Sources of carbonaceous aerosols and deposited black carbon in the Arctic in winter-spring: implications for radiative forcing, Atmos. Chem. Phys., 11, 1245312473, doi:10.5194/acp-11-12453-2011, 2011.

Wofsy, S. C., Team, H. S., Team, C. M., and Team, S.: HIAPER Pole-to-Pole Observations (HIPPO): fine-grained, globalscale measurements of climatically important atmospheric gases and aerosols, Philos. T. R. Soc. A, 369, 2073-2086, doi:10.1098/rsta.2010.0313, 2011.

Zarzycki, C. M. and Bond, T. C.: How much can the vertical distribution of black carbon affect its global direct radiative forcing?, Geophys. Res. Lett., 37, L20807, doi:10.1029/2010g1044555, 2010.

Zhang, G. J. and Mcfarlane, N. A.: Sensitivity of Climate Simulations to the Parameterization of Cumulus Convection in the Canadian Climate Center General-Circulation Model, Atmos. Ocean., 33, 407-446, 1995.

Zhang, R. Y., Khalizov, A. F., Pagels, J., Zhang, D., Xue, H. X., and McMurry, P. H.: Variability in morphology, hygroscopicity, and optical properties of soot aerosols during atmospheric processing, P. Natl. Acad. Sci. USA, 105, 10291-10296, doi:10.1073/pnas.0804860105, 2008. 